\title{
The Crystal Structure of $\mathbf{R h}_{2} \mathrm{Al}_{9}$ and $\mathrm{Ir}_{2} \mathrm{Al}_{9}$
}

\author{
LARS·ERIK EDSHAMMAR
}

Institute of Inorganic and Physical Chemistry, University of Stockholm, S.113 59 Stockholm,
Sweden

The phases $\mathrm{Rh}_{2} \mathrm{Al}_{9}$ and $\mathrm{Ir}_{2} \mathrm{Al}_{9}$ have been synthesized and found to be isomorphous with $\mathrm{Co}_{2} \mathrm{Al}_{9}$. The unit cell dimensions are

$$
\begin{aligned}
& \mathrm{Rh}_{2} \mathrm{Al}_{9}: a=6.352, \quad b=6.428, \quad c=8.721 \AA \text { and } \beta=94.81^{\circ} \\
& \mathrm{Ir}_{2} \mathrm{Al}_{8}: \quad a=6.378, \quad b=6.430, \quad c=8.732 \AA \text { and } \beta=94.77^{\circ}
\end{aligned}
$$

The crystal structure of $\mathrm{Rh}_{2} \mathrm{Al}_{8}$ has been refined with least squares techniques to an $R$ value of 0.09 using three-dimensional Weissenberg data. The interatomic distances are compared to those in $\mathrm{Co}_{\mathbf{2}} \mathrm{Al}_{\mathbf{9}}$.

The existence of the phase $\mathrm{Rh}_{2} \mathrm{Al}_{9}$ was first established by Ferro et al. in their phase analysis investigation of the rhodium-aluminium system. ${ }^{1}$ However, no crystallographic data were given for this compound. No similar investigation seems to have been reported on the iridium-aluminium system. An $\mathrm{X}$-ray investigation on $\mathrm{Rh}_{2} \mathrm{Al}_{9}$ and $\mathrm{Ir}_{2} \mathrm{Al}_{9}$, which will be described in the present paper, shows that the compounds are isostructural and of the $\mathrm{Co}_{2} \mathrm{Al}_{9}$ type.

\section{EXPERIMENTAL}

An alloy of the composition $\mathrm{RhAl}_{4.5}$ was prepared from rhodium powder (L. Light \& Co., about $99.98 \%$ ) and aluminium ribbon (E. Merck AG., at least $99.99 \%$ ) by arc-melting in an argon atmosphere with the sample resting on a water-cooled copper base. The alloy was then lump-annealed for four days at $660^{\circ} \mathrm{C}$ in a sealed evacuated silica tube. The heat-treatment was discontinued by quenching in water. The alloy thus obtained was crystalline and good single crystals suitable for a Weissenberg recording were easily found. No chemical analysis was performed as the weight loss during the preparation was very small.

The compound $\mathrm{Ir}_{2} \mathrm{Al}_{9}$ was prepared in an analogous way. The iridium powder used has a purity of $99.98 \%$ according to the supplier (L. Light \& Co., about $99.98 \%$ ). No useful single crystals could be found in the quenched product.

Powder patterns were obtained in a Guinier-Hägg camera with CuK$K \alpha_{1}$ radiation $(\lambda=1.54050 \AA)$ and with $\mathrm{KCl}(a=6.2919 \AA)$ as an internal standard.

Single crystal data of $\mathrm{Rh}_{2} \mathrm{Al}_{9}$ were collected with a Nonius Weissenberg camera using $\mathrm{CuK}$ radiation. The multiple film technique was used and the intensities were estimated visually by comparison with an intensity scale prepared from a suitable reflection of the zero layer.

The computational work was carried out on the CD 3600 computer at Uppsala. Lp correction was performed with a program called DRF (by A. Zalkin, modified by 
R. Liminga and J.-O. Lundgren, Uppsala.) and least squares refinements of positional parameters and temperature factors were performed with LALS (by A. Zalkin, modified by R. Liminga, J.-O. Lundgren and C.-I. Brändén).

\section{THE PHASE $\mathrm{Rh}_{2} \mathrm{Al}_{9}$}

A small irregular crystal (all dimensions less than $0.02 \mathrm{~mm}$ ) found in the quenched sample of the composition $\mathrm{RhAl}_{4.5}$ was used in the single crystal work. The Weissenberg data obtained showed clearly that they were generated by a structure isomorphous with the earlier known $\mathrm{Co}_{2} \mathrm{Al}_{9} .{ }^{2}$ Approximate cell dimensions were determined from these data. The powder pattern of the sample was indexed and after a least squares refinement the following unit cell dimensions were obtained:

$$
a=6.352 \pm 0.001 \AA, b=6.428 \pm 0.001 \AA ⿻ \pm_{\beta=94.81^{\circ} \pm 0.02^{\circ}}^{\AA}, c=8.721 \pm 0.001 \AA,
$$

The powder pattern of $\mathrm{Rh}_{2} \mathrm{Al}_{9}$ is given in Table 1 . No change of this pattern was observed for alloys of different compositions around $\mathrm{RhAl}_{4.5}$.

\begin{tabular}{|c|c|c|c|c|}
\hline$h k l$ & $\sin ^{2} \theta_{\mathrm{obs}}$ & $\sin ^{2} \theta_{\text {calc }}$ & $I_{\text {obs }}$ & $I_{\text {calc }}$ \\
\hline 100 & - & 0.01481 & - & 0.2 \\
\hline 0111 & 0.02225 & 0.02222 & $\mathrm{~m}$ & \\
\hline 110 & 0.02919 & 0.02917 & st & 96.6 \\
\hline 002 & 0.03147 & 0.03142 & $\mathrm{w}$ & 23.1 \\
\hline$\overline{1} 111$ & 0.03515 & 0.03522 & $\mathrm{~m}$ & 76.3 \\
\hline 111 & 0.03886 & 0.03883 & $\mathbf{m}$ & \\
\hline $\begin{array}{lll}1 & 0 & 2\end{array}$ & 0.04264 & 0.04262 & $\mathrm{~m}$ & \\
\hline 012 & 0.04576 & 0.04578 & $\mathbf{m}$ & 62.1 \\
\hline 102 & 0.04987 & 0.04985 & $\mathrm{~m}$ & 45 \\
\hline 112 & 0.05699 & 0.05697 & vw & 9.3 \\
\hline 020 & - & 0.05744 & - & 0.1 \\
\hline 200 & 0.05927 & 0.05923 & $\mathbf{m}$ & 46 \\
\hline 112 & 0.06431 & 0.06421 & vw & 7 \\
\hline 021 & 0.06529 & 0.06529 & $\mathrm{~m}$ & 59 \\
\hline 120 & - & 0.07225 & - & 1 \\
\hline 210 & - & 0.07359 & - & 0 \\
\hline 211 & 0.07790 & 0.07783 & vw & 5 \\
\hline 121 & - & 0.07829 & - & 0.1 \\
\hline 121 & 0.08190 & 0.08191 & $\mathrm{vw}$ & 4 \\
\hline 202 & 0.08335 & 0.08342 & $\mathrm{w}$ & 14.7 \\
\hline 211 & & 0.08506 & & \\
\hline 013 & 0.08509 & $\left\{\begin{array}{l}08506 \\
0.08\end{array}\right.$ & $w$ & $\{19$ \\
\hline 022 & - & 0.08886 & - & 0 \\
\hline$\overline{1} 13$ & 0.09443 & 0.09444 & - & 2 \\
\hline$\overline{2} 12$ & - & 0.09777 & - & 1 \\
\hline 202 & - & 0.09789 & - & \\
\hline$\overline{1} 22$ & 0.09999 & 0.10005 & $\mathbf{w}$ & 23 \\
\hline 113 & 0.10531 & 0.10530 & vw & 3 \\
\hline 122 & 0.10731 & 0.10729 & w & 32 \\
\hline 212 & 0.11221 & 0.11225 & $\mathbf{m}$ & 59 \\
\hline$\overline{2} 20$ & - & 0.11667 & - & 0 \\
\hline$\overline{2} 21$ & 0.12092 & 0.12090 & $\mathbf{m}$ & 44. \\
\hline 04 & 0.12574 & 0.12569 & vw & 6.8 \\
\hline
\end{tabular}

Table 1. The powder pattern of $\mathrm{Rh}_{2} \mathrm{Al}_{9}\left(\mathrm{CuK} \alpha_{1}, \lambda=1.5405 \AA\right)$.

Acta Chem. Scand. 22 (1968) No. 9 
Table 2. Final atomic parameters of $\mathrm{Rh}_{2} \mathrm{Al}_{0}$. Space group: $P 2_{1} / c ; Z=2$.

$\begin{array}{lcccccccc} & x & \sigma(x) & y & \sigma(y) & z & \sigma(z) & B \AA^{2} & \sigma(B) \\ \mathrm{Rh} \text { in } 4 e & 0.2630 & 0.0003 & 0.62194 & 0.0005 & 0.3313 & 0.0002 & 0.77 & 0.06 \\ \mathrm{Al}_{\mathbf{0}} \text { in } 2 a & - & - & - & - & - & - & 1.80 & 0.21 \\ \mathrm{Al}_{1} \text { in } 4 e & 0.4031 & 0.0011 & 0.9790 & 0.0020 & 0.2678 & 0.0008 & 1.32 & 0.14 \\ \mathrm{Al}_{2} \text { in } 4 e & 0.0951 & 0.0011 & 0.2874 & 0.0019 & 0.2277 & 0.0008 & 1.21 & 0.14 \\ \mathrm{Al}_{3} \text { in } 4 e & 0.3895 & 0.0011 & 0.1956 & 0.0019 & 0.9982 & 0.0008 & 1.15 & 0.14 \\ \mathrm{Al}_{\text {, in } 4 e} & 0.2161 & 0.0012 & 0.6099 & 0.0019 & 0.0415 & 0.0008 & 1.38 & 0.14\end{array}$

The atomic parameters given by Douglas ${ }^{2}$ for $\mathrm{Co}_{2} \mathrm{Al}_{9}$ were adopted as starting values in the least squares refinement. This was based on 380 measured reflections, all of them independent, collected with the crystal rotating around the monoclinic axis. The weights were calculated using Hughes' weighting scheme. Atomic scattering factors including the real part of the dispersion correction were taken from the International Tables for $\bar{X}$-Ray Crystallography.

Table 3. Interatomic distances in $\mathrm{Rh}_{2} \mathrm{Al}_{0}$ and their e.s.d.'s in $\AA$.

\begin{tabular}{|c|c|c|c|c|c|}
\hline $\begin{array}{r}\mathbf{R h}-\mathbf{A l}_{\mathbf{0}} \\
\mathbf{A l}_{\mathbf{4}} \\
\mathbf{A l}_{\mathbf{2}} \\
\mathbf{A l}_{\mathbf{1}} \\
\mathbf{A l}_{\mathbf{2}} \\
\mathbf{A l}_{\mathbf{1}} \\
\mathbf{A l}_{\mathbf{4}} \\
\mathbf{A l}_{\mathbf{3}} \\
\mathbf{A l}_{\mathbf{3}}\end{array}$ & $\begin{array}{l}2.446 \\
2.521 \\
2.525 \\
2.529 \\
2.533 \\
2.539 \\
2.551 \\
2.595 \\
2.599\end{array}$ & $\begin{array}{l}0.002 \\
0.009 \\
0.008 \\
0.008 \\
0.012 \\
0.012 \\
0.011 \\
0.012 \\
0.008\end{array}$ & $\begin{array}{rr}\mathbf{A l}_{3}-\mathbf{R h} \\
\mathbf{R h} \\
\mathbf{A l}_{1} \\
\mathbf{A l}_{\mathbf{0}} \\
\mathbf{A l}_{4} \\
\mathbf{A l}_{3} \\
\mathbf{A l}_{2} \\
\mathbf{A l}_{1} \\
\mathbf{A l}_{2} \\
\mathbf{A l}_{4}\end{array}$ & $\begin{array}{l}2.595 \\
2.599 \\
2.728 \\
2.776 \\
2.847 \\
2.879 \\
2.886 \\
2.906 \\
2.912 \\
2.918\end{array}$ & $\begin{array}{l}0.012 \\
0.008 \\
0.014 \\
0.008 \\
0.011 \\
0.023 \\
0.011 \\
0.016 \\
0.011 \\
0.017\end{array}$ \\
\hline $\begin{array}{r}\mathrm{Al}_{0}-2 \mathrm{Rh} \\
2 \mathrm{Al}_{2} \\
2 \mathrm{Al} l^{2}\end{array}$ & $\begin{array}{l}2.446 \\
2.742 \\
2.776\end{array}$ & $\begin{array}{l}0.002 \\
0.011 \\
0.008\end{array}$ & $\begin{array}{l}\mathrm{Al}_{1} \\
\mathrm{Al}_{1}\end{array}$ & $\begin{array}{l}2.961 \\
2.982\end{array}$ & $\begin{array}{l}0.014 \\
0.013\end{array}$ \\
\hline $\begin{array}{l}2 \mathrm{Al}_{3} \\
2 \mathrm{Al}_{4}\end{array}$ & $\begin{array}{l}2.848 \\
2.867\end{array}$ & $\begin{array}{l}0.010 \\
0.012\end{array}$ & $\begin{array}{r}\mathbf{A l}_{\mathbf{l}}-\mathbf{R h} \\
\mathbf{R h} \\
\mathbf{A l}_{\mathbf{2}}\end{array}$ & $\begin{array}{l}2.521 \\
2.551 \\
2.781\end{array}$ & $\begin{array}{l}0.009 \\
0.011 \\
0.016\end{array}$ \\
\hline $\begin{array}{r}\mathrm{Al}_{1}-\mathbf{R h} \\
\mathrm{Rh} \\
\mathrm{Al}_{3} \\
\mathbf{A l}_{2} \\
\mathbf{A l}_{4} \\
\mathrm{Al}_{3} \\
\mathbf{A l}_{4} \\
\mathbf{A l}_{3} \\
\mathbf{A l}_{3} \\
\mathbf{A l}_{4}\end{array}$ & $\begin{array}{l}2.529 \\
2.539 \\
2.728 \\
2.786 \\
2.812 \\
2.906 \\
2.941 \\
2.961 \\
2.982 \\
3.247\end{array}$ & $\begin{array}{l}0.008 \\
0.012 \\
0.014 \\
0.014 \\
0.012 \\
0.016 \\
0.011 \\
0.014 \\
0.013 \\
0.015\end{array}$ & $\begin{array}{l}\mathrm{Al}_{1} \\
\mathrm{Al}_{3} \\
\mathrm{Al}_{0} \\
\mathrm{Al}_{3} \\
\mathrm{Al}_{1} \\
\mathrm{Al}_{2} \\
\mathrm{Al}_{4} \\
\mathrm{Al}_{2} \\
\mathrm{Al}_{1}\end{array}$ & $\begin{array}{l}2.812 \\
2.847 \\
2.867 \\
2.918 \\
2.941 \\
3.013 \\
3.118 \\
3.151 \\
3.247\end{array}$ & $\begin{array}{l}0.012 \\
0.011 \\
0.012 \\
0.017 \\
0.011 \\
0.011 \\
0.016 \\
0.012 \\
0.015\end{array}$ \\
\hline $\begin{array}{r}\mathbf{A l}_{2}-\mathbf{R h} \\
\mathbf{R h} \\
\mathbf{A l}_{0} \\
\mathbf{A l}_{\mathbf{3}} \\
\mathbf{A l}_{1} \\
\mathbf{A l}_{\mathbf{0}} \\
\mathbf{A l}_{3} \\
\mathbf{A l}_{3} \\
\mathbf{A l}_{4} \\
\mathbf{A l}_{4}\end{array}$ & $\begin{array}{l}\mathbf{2 . 5 2 5} \\
2.533 \\
2.742 \\
2.781 \\
2.786 \\
2.848 \\
2.886 \\
2.912 \\
3.013 \\
3.151\end{array}$ & $\begin{array}{l}0.008 \\
0.012 \\
0.011 \\
0.016 \\
0.014 \\
0.010 \\
0.011 \\
0.011 \\
0.011 \\
0.012\end{array}$ & & & \\
\hline
\end{tabular}


The following 25 parameters were refined: four scale factors corresponding to each one of the collected layer-lines, 15 positional parameters and 5 isotropic temperature factors. After six cycles of full-matrix refinement, an $R$ value of 0.10 was obtained for the 380 reflections. 19 of the reflections were rejected by the program and if these were not included the $R$-value was 0.09 . The final structural data of $\mathrm{Rh}_{2} \mathrm{Al}_{9}$ are given in Table 2 and the interatomic distances are given in Table 3.

\section{THE PHASE $\operatorname{Ir}_{2} \mathrm{Al}_{9}$}

A comparison between the powder films taken from $\operatorname{Ir}_{2} \mathrm{Al}_{9}$ and $\mathrm{Rh}_{2} \mathrm{Al}_{9}$ showed the structures to be isomorphous. The cell dimensions of $\operatorname{Ir}_{2} \mathrm{Al}_{9}$ were refined by the least squares method and the following constants were found:

$$
a=6.378 \pm 0.001 \AA, b=6.430 \pm 0.001 \AA, c=8.732 \pm 0.002 \AA,
$$

The powder pattern of $\mathrm{Ir}_{2} \mathrm{Al}_{9}$ is given in Table 4. No changes of the unit cell dimensions were observed for alloys of different compositions around $\operatorname{IrAl} \mathrm{Al}_{4.5}$.

\begin{tabular}{|c|c|c|c|}
\hline$h k l$ & $\sin ^{2} \theta_{\text {obs }}$ & $\sin ^{2} \theta_{\text {calc }}$ & $I_{\mathrm{obs}}$ \\
\hline 100 & 0.01472 & 0.01469 & vvw \\
\hline 011 & 0.02214 & 0.02218 & $\mathrm{~m}$ \\
\hline $\begin{array}{lll}1 & 1 & 0\end{array}$ & 0.02906 & 0.02904 & vst \\
\hline 002 & 0.03138 & 0.03134 & $\mathrm{~m}$ \\
\hline$\overline{1} 11$ & 0.03503 & 0.03509 & st \\
\hline 111 & 0.03866 & 0.03866 & st \\
\hline 102 & 0.04244 & 0.04246 & st \\
\hline 012 & 0.04570 & 0.04569 & st \\
\hline 102 & 0.04960 & 0.04960 & st \\
\hline 112 & 0.05687 & 0.05681 & $\mathbf{w}$ \\
\hline 020 & - & 0.05740 & - \\
\hline 200 & 0.05874 & 0.05874 & st \\
\hline 116 & 0.06406 & 0.06394 & vw \\
\hline 021 & 0.06529 & 0.06523 & st \\
\hline 120 & - & 0.07209 & - \\
\hline 210 & - & 0.07309 & - \\
\hline$\overline{2} 11$ & 0.07736 & 0.07736 & vw \\
\hline$\overline{1} 21$ & 0.07813 & 0.07814 & vvw \\
\hline 121 & 0.08173 & 0.08171 & $\mathrm{w}$ \\
\hline 202 & 0.08301 & 0.08295 & $\mathbf{w}$ \\
\hline 211 & - & 0.08449 & - \\
\hline & 0.08492 & 0.08487 & $\mathbf{m}$ \\
\hline 022 & - & 0.08874 & - \\
\hline $\begin{array}{lll}0 & 1 & 3\end{array}$ & - & 0.09420 & - \\
\hline 2 & - & 0.09722 & - \\
\hline$\overline{2} 12$ & 0.09741 & 0.09730 & vvw \\
\hline 122 & 0.09980 & 0.09986 & $\mathrm{w}$ \\
\hline & - & 0.10490 & - \\
\hline & 0.10697 & 0.10700 & $\mathbf{w}$ \\
\hline & 0.11161 & 0.11157 & $\mathrm{~m}+$ \\
\hline & - & 0.11614 & - \\
\hline & 0.12035 & 0.12041 & $\mathrm{~m}+$ \\
\hline & - & 0.12536 & \\
\hline
\end{tabular}

Table 4. The powder pattern of $\operatorname{Ir}_{2} \mathrm{Al}_{9}\left(\mathrm{CuK \alpha _{1 }}, \lambda=1.5405 \AA\right)$.

Acta Chem. Scand. 22 (1968) No. 9 


\section{DISCUSSION}

The structure of $\mathrm{Co}_{2} \mathrm{Al}_{9}$ has been described by Schubert ${ }^{3}$ as a stacking of alternating quadratic layers of $\mathrm{Al}$ and $\mathrm{CuAl}_{2}$.

The structure of $\mathrm{Rh}_{2} \mathrm{Al}_{9}$ is strictly isomorphous with $\mathrm{Co}_{2} \mathrm{Al}_{9}$. The differences found between the two structures depend on the fact that the rhodium radius is about $0.1 \AA$ larger than the cobalt radius. Thus, the $\mathrm{Rh}-\mathrm{Al}$ distances in $\mathrm{Rh}_{2} \mathrm{Al}_{9}$ range from $2.45 \AA$ to $2.60 \AA$ and have an average value of $2.54 \AA$, whilst the $\mathrm{Co}-\mathrm{Al}$ distances in $\mathrm{Co}_{2} \mathrm{Al}_{9}$ lie within the range 2.37-2.50 $\mathrm{A}$, with an average of $2.47 \AA$. This comparison is in concordance with a similar one made for the $\mathrm{Rh}-\mathrm{Al}$ and $\mathrm{Co}-\mathrm{Al}$ bonds in the two isostructural compounds $\mathrm{Rh}_{2} \mathrm{Al}_{5}$ and $\mathrm{Co}_{2} \mathrm{Al}_{5} \cdot{ }^{4}$

The interaluminium distances in $\mathrm{Rh}_{2} \mathrm{Al}_{9}$ range from values that are the same up to values $0.12 \AA$ larger than those of the equivalent distances in $\mathrm{Co}_{2} \mathrm{Al}_{9}$. This is also in agreement with comparisons between $\mathrm{Rh}_{2} \mathrm{Al}_{5}$ and $\mathrm{Co}_{2} \mathrm{Al}_{5}$.

Further studies on the $\mathrm{Rh}-\mathrm{Al}$ and the $\mathrm{Ir}-\mathrm{Al}$ systems are in progress.

Acknowledgements. The author wishes to thank Professor Arne Magnéli for his interest in this work and for his valuable comments on the manuscript.

The investigation has been made possible through the support of the Swedish Natural Science Research Council and a scholarship from the Th. Nordströms testamentsfond of the Royal Academy of Science.

\section{REFERENCES}

1. Ferro, R., Rambaldi, G. and Capelli, R. Atti Accad. Nazl. Lincei, Rend. Classe Sci. Fis. Mat. Nat. 36 (1954) 491.

2. Douglas, A. M. B. Acta Cryst. 3 (1950) 19.

3. Schubert, K. Kristallstrukturen zweikomponentiger Phasen, Berlin/Göttingen/Heidelberg 1964, p. 302.

4. Edshammar, L.-E. Acta Chem. Scand. 21 (1967) 647.

Received April 24, 1968. 